\title{
Elevated Interleukin-38 Level Associates with Clinical Response to Atorvastatin in Patients with Hyperlipidemia
}

\author{
Ning Yang Yanqiu Song Bo Dong Yang Li Lu Kou Jingyu Yang Qin Qin \\ Department of Cardiology, Tianjin Chest Hospital, Tianjin, China
}

\section{Key Words}

Hyperlipidemia $・$ IL-38 $・$ Interleukin-38 • Atorvastatin • Atherosclerosis

\begin{abstract}
Background/Aims: Hyperlipidemia is a risk factor for various cardiovascular and metabolic disorders. And it is tightly related to chronic inflammation. Interleukin-38 (IL-38) represents a new member of anti-inflammatory cytokines. Thus we studied the important role of IL38 in hyperlipidemia development and treatment. Methods: The mRNA level of IL-38 in PBMCs (peripheral blood mononuclear cells) and serum IL-38 levels in hyperlipidemia patients and healthy controls were measured by real-time polymerase chain reaction (RT$P C R$ ) and enzyme-linked immunoassay (ELISA). The hyperlipidemia patients were further divided into two groups (Sensitive and Resistant Group) according to their clinical response to Atorvastatin therapy. Finally, the effects of IL-38 on hyperlipidemia was evaluated in the mice model. Results: Data showed that the IL-38 mRNA and serum protein levels were higher in patients with hyperlipidemia compared with healthy controls. And the IL-38 mRNA and serum protein levels were higher in patients sensitive to Atorvastatin therapy than the resistant group. In vitro, IL-38 inhibited the production of IL-6, IL-1 $\beta$ and CRP in PBMCs of patients with hyperlipidemia. In the mice model of hyperlipidemia, IL-38 was also elevated during the hyperlipidemia development. Furthermore, the IL-38 over-expressed by adeno-associated virus significantly inhibited the hyperlipidemia development, inflammatory factor secretion and also the atherosclerosis process. Conclusion: Thus our data showed that IL-38 might present protective effects on hyperlipidemia treatment.
\end{abstract}

(C) 2018 The Author(s)

Published by S. Karger AG, Basel

\section{Introduction}

High plasma lipids are risk factors for various cardiovascular and metabolic disorders such as atherosclerosis, obesity and metabolic syndrome [1-4]. Cardiovascular disease itself is the leading cause of death in the world $[5,6]$. Statins represent a highly effective therapeutic approach for reducing plasma lipids and related complications [7]. However, the 


\section{Cellular Physiology Cell Physiol Biochem 2018;49:653-661 and Biochemistry Published \begin{tabular}{l|l} 
DOI: 10.1159/000493029 & $\begin{array}{l}\text { C } 2018 \text { The Author(s). Published by S. Karger AG, Basel } \\
\text { www.karger.com/cpb }\end{array}$ \\
\hline
\end{tabular}}

Yang et al.: Elevated IL-38 Associates with Atorvastatin Response

responsiveness to statin is influenced by environmental or genetic factors [8]. Only 20-40\% individuals could benefit from the statin therapy, highlighting a need for new approaches to lower plasma lipids [9-15].

Chronic inflammation is tightly association with hyperlipidemia [16-19]. Interleukin-38 (IL-38) is a new identified anti-inflammatory factor in the IL-1 ligand family [20, 21]. IL-38 binds to IL-36R similar to IL-36Ra, which can inhibit the pro-inflammation function of IL-36 [22]. Moreover, polymorphisms in IL-38 were associated with CRP concentrations in humans [23] and were found to be significantly associated with coronary artery disease (CAD) [24]. In addition, IL-38 mRNA was found in human atheromatous plaques of coronary artery disease patients [25]. These results suggest an important role for IL-38 in cardiovascular diseases, indicating that IL-38 might also play an important role in hyperlipidemia which contributes to cardiovascular disease development. Thus, we conducted the present study to investigate the role of IL-38 in hyperlipidemia development and treatment.

\section{Materials and Methods}

\section{Patients}

Patients with primary hyperlipidemia were selected from the outpatients, who were evaluated for the presence of CAD, at the cardiovascular disease clinics affiliated with Tianjin Chest Hospital between January 2010 and October 2016. The study protocol was approved by the Ethics Committees of Tianjin Chest Hospital (code number 200957E45). All the patients signed an informed consent form. Women as well as individuals with serum triglycerides above $400 \mathrm{mg} / \mathrm{dl}$ or with thyroid disease (TSH $\geq 5$ or $\leq 0.4 \mu \mathrm{U} /$ $\mathrm{dl}$ ), high cardiovascular risk, renal failure ( $\mathrm{SCr} \geq 2 \mathrm{mg} / \mathrm{dl}$ for women, $\mathrm{SCr} \geq 2.5 \mathrm{mg} / \mathrm{dl}$ for men), liver diseases (ALT $\geq 40 \mathrm{mg} / \mathrm{dl}$ ), diabetes mellitus (who had two consecutive $\mathrm{FBS} \geq 126 \mathrm{mg} / \mathrm{dl}$ ), severe psychological disorders, physical disabilities, cancer, Alzheimer's disease, AIDs (acquired immune deficiency syndrome) or other communicable diseases, and individuals treated with oral contraceptives and lipid-lowering drugs were not enrolled in the study. Four weeks before the study, all the subjects visited a dietitian and were instructed to consume a low-cholesterol diet (total daily fat intake 25 to 35\% of total calories, trans fats to less than $7 \%$ of calories) [1, 26, 27]. Information on age, gender, body mass index (BMI), blood pressure or anti-hypertensive drug history, physical activity (20 minutes walking per day), family history and past medical history of each patient were recorded. Alcoholic and smoker patients were excluded from the study due to the limited numbers.

A total of 424 hyperlipidemia patients were recruited, whose TG and TC values were higher than 150 and $200 \mathrm{mg} / \mathrm{dl}$, respectively. Healthy controls $(\mathrm{n}=408)$ with normolipidemia were recruited from our health examination center at the same time (TG of $<150 \mathrm{mg} / \mathrm{dl}$ and $\mathrm{TC}$ of $<200 \mathrm{mg} / \mathrm{dl}$ ) [1, 26, 27]. All participants signed an informed consent form. All methods were performed in accordance with the relevant guidelines and regulations for both mice and human.

Patients were treated with $10 \mathrm{mg}$ Atorvastatin orally once daily for four weeks. The patients response to the Atorvastatin were defined as their ideal LDL goal ( $\mathrm{LDL}<115 \mathrm{mg} / \mathrm{dl}$ ) $[1,26,27]$. The cardiovascular risk was assessed by Framingham Risk Score (FRS) and Atherosclerotic Cardiovascular Disease risk score (ASCVD) [28-30].

\section{Lipid measurement}

One week before and four weeks after Atorvastatin administration, peripheral blood samples were collected from the individuals after an overnight fasting (8-12 h) [1]. Serum samples were collected, stored at $4{ }^{\circ} \mathrm{C}$, and analyzed within 24 hours. Total serum cholesterol, HDL, LDL and triglyceride concentrations were determined on an Abbott Architect C-16000 by commercially available colorimetric kits (Abbott Architect C-16000 dedicated kits). Before and after the administration of Atorvastatin, ALT and creatinine kinase were determined to detect the possible adverse drug reactions.

RNA extraction and real-time polymerase chain reaction (RT-PCR)

Total RNA was extracted from PBMCs with Trizol (Invitrogen, Carlsbad, CA, USA) according to the manufacturer's instructions. Then the quantity and purity of RNA was determined by absorbance on a 


\section{Cellular Physiology Cell Physiol Biochem 2018;49:653-661

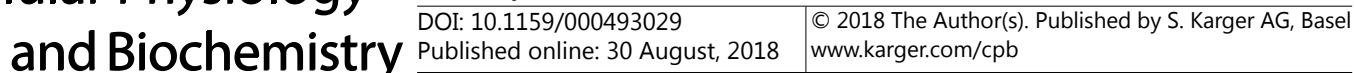

Yang et al.: Elevated IL-38 Associates with Atorvastatin Response

FilterMax F5 Multi-Mode Microplate Reader (Sunnyvale, California, USA) at $260 \mathrm{~nm}$ and $280 \mathrm{~nm}$. Samples with ratios from 1.8 to 2.0 were accepted for next reverse transcription reaction. cDNA was prepared by using the iScript ${ }^{\mathrm{TM}}$ cDNA Synthesis kit (Bio-Rad, USA). $\beta$-actin was used as internal control. RT-PCR amplification reaction was prepared with the SYBR Green PCR kit (Bio-rad, USA) and performed using the 7500 fast RealTime PCR system (Applied Biosystems, USA). PCR products were verified by melting curve analysis. Relative mRNA levels of target genes were calculated by the $2^{-\Delta \Delta c t}$ method.

\section{Enzyme-linked immunoassay (ELISA)}

The levels of plasma IL-38 (Adipogen), IL-6 (BD Biosciences), IL-1 $\beta$ (BD Biosciences) and CRP (Biocalvin) were measured by an enzyme-linked immunosorbent assay (ELISA), following the manufacturer's instructions. The minimal detectable concentration was $40 \mathrm{pg} / \mathrm{mL}$ for IL-38. The ELISA intra-assay and interassay coefficients of variation were $<5 \%$ and $<10 \%$, respectively. All of the samples were measured in duplicate.

\section{Recombinant human IL-38 protein expression and purification}

Interleukin-38 gene (Homo Species) was amplified from cDNA of peripheral blood mononuclear cells. The PCR fragments were double digested with restriction endonucleases and ligated into the prokaryotic expression vector. The fusion protein was expressed in a stable prokaryotic expression system. The plasmids of positive clones were then sequenced by Sanger method with 100\% identify with the published sequence. The induced and un-induced cultures were analyzed by SDS-PAGE to identify the expression of recombinant protein. The harvested cells were resuspended in NaCl-Tris-HCl buffer, sonicated in an ice bath, $12000 \mathrm{rpm}$ centrifuged for $30 \mathrm{~min}$, and then the supernatant were collected. The supernatant were added to His Trap $\mathrm{HP}, 1 \mathrm{ml}$ column (GE) that had been equilibrated with $\mathrm{NaCl}$-Tris-HCl buffer. Different concentrations of imidazole buffer were used to elute the recombinant protein. Collected target protein peaks were examined by SDS-PAGE electrophoresis and immunoblot analysis using anti-human IL-38 antibody (Abcam, UK). The eluted recombinant protein was dialyzed in PBS at $4^{\circ} \mathrm{C}$ for overnight. The concentration was detected by Brandford methods, and the recombinant protein was stored at $-20^{\circ} \mathrm{C}$.

\section{Cell culture condition}

Culture medium is consisted of RPMI 1640 (Hyclone, Thermo, USA) supplemented with 10\% Fetal Calf Serum (Hyclone, Thermo, USA), $100 \mathrm{IU} / \mathrm{ml}$ penicillin and $100 \mu \mathrm{g} / \mathrm{ml}$ streptomycin (Hyclone, Thermo, USA). Whole PBMCs were cultured in 24 well, flat-bottomed plates $\left(5 \times 10^{5}\right.$ cells $/ \mathrm{ml} /$ well $)$ for 24 hours. PBMCs were stimulated with or without human recombinant IL-38 at $50 \mathrm{ng} / \mathrm{ml}$ for 24 hours and then incubated further with LPS $(1 \mu \mathrm{g} / \mathrm{ml})$ for 6 hours. Total RNAs were extracted, and cytokine transcriptions were analyzed by RT-PCR. Culture supernatants were harvested and froze at $-80^{\circ} \mathrm{C}$ for later cytokine analysis by ELISA.

\section{Animal study}

The 6-8 weeks old ApoE-deficient (ApoE-/-) mice on a C57Bl/6J background (The Jackson Laboratory, Bar Harbor, ME) were housed in specific pathogen-free conditions. Only male mice were used in these experiments to avoid the effects of hormonal changes on plasma lipids. The study was approved by the Research Ethics Committee of Tianjin Chest Hospital. Mice were housed in an air-conditioned room at $22^{\circ} \mathrm{C} \pm 0.5^{\circ} \mathrm{C}$ with a 12 -hour lighting schedule (7:00-19:00). Mice were kept on a normal chow diet (Research Diets) or fed a high-cholesterol diet (HCD; 21\% fat and 0.15\% cholesterol; Research Diets).

Diet-induced atherosclerosis was induced by feeding ApoE ${ }^{-/-}$mice an HCD for 12 weeks. Before tissue or blood collection, mice were starved for 16 hours, unless otherwise indicated. Blood was collected via the tail vein. The aorta and carotid arteries were harvested after in situ perfusion fixation with $4 \%$ paraformaldehyde (Carl Roth $\mathrm{GmbH}$, Karlsruhe, Germany). For quantification of atherosclerosis, animals were euthanized by intraperitoneal pentobarbital injection $(100 \mathrm{mg} / \mathrm{kg})$ and aortic trees were dissected and stained with oil red 0 . The en face lesion size was analyzed with the ImageJ software.

Production and in vivo Delivery of Adeno-associated Virus

Vector construction, production, and in vivo delivery of adeno-associated virus (AAV) were performed based on the AAV helper-free system (Agilent). The recombinant adenoviral vector pAAV-IL38 was 
constructed by cloning the cDNA encoding region into pAAV-ITR. The vector pAAV-GFP encoding green fluorescence protein was used as a negative control. Recombinant AAVs were produced by HEK293 cells (ATCC) transfected with pAAV-ITR vectors together with pAAV-RC and pHelper plasmids, and then purified by discontinuous iodixanol gradient centrifugation. Purified recombinant AAVs were concentrated and desalted by centrifugation through Amicon Ultra 30K filters (Millipore). For in vivo delivery, recombinant AAVs equivalent to $1.0 \times 10^{12}$ viral genome copies were delivered though mouse tail vein. AAVs were injected at week $0,3,6,9$ after feeding the HCD.

\section{Statistical analysis}

Data were expressed as mean \pm SE or median plus interquartile range and analyzed by Graphpad Prism V.5.00 software (GraphPad Software, San Diego CA, USA). Comparisons between groups were made using nonparametric Mann-Whitney U-test. $p$ values under 0.05 were considered statistically significant.

\section{Results}

\section{Elevated IL-38 in Patients with Hyperlipidemia}

The clinical characteristics of all patients and healthy controls were summarized in Table 1. The healthy and hyperlipidemia patients did not differ in age and BMI (Table 1). Hyperlipidemia patients` TC, TG and LDL levels were significantly higher than those in control (Table 1) while the HDL levels were lower (Table 1). Furthermore, both mRNA and protein levels of IL-38 were significantly elevated in the hyperlipidemia patients than healthy controls (Table 1, Fig. 1A-1B).

\section{IL-38 Associates with Clinical Responses to Atorvastatin}

Then the patients were divided into two groups, Atorvastatin sensitive and resistant

Fig. 1. Elevation of IL-38 level in hyperlipidemia patients and association with clinical response to Atorvastatin therapy. (A) IL-38 mRNA levels in PBMCs from hyperlipidemia patients $(n=424)$ and healthy controls $(n=408)$ were determined by realtime PCR. * $\mathrm{P}<0.05$. (B) IL-38 protein levels in the serum from hyperlipidemia patients $(n=424)$ and healthy controls $(n=408)$ were determined by ELISA. Result is depicted as box plots; middle line indicates median; bottom of box, 25th percentile; and top of box, 75th percentile. ${ }^{*} \mathrm{P}<0.05$. (C) IL-38 mRNA levels in PBMCs from hyperlipidemia patients sensitive to statin treatment $(\mathrm{n}=137)$, resistant to statin treatment $(n=287)$ and healthy controls $(n=408)$ were determined by real-time PCR. * $\mathrm{P}<0.05$. (D) IL38 protein levels in the serum from hyperlipidemia patients sensitive to statin treatment $(\mathrm{n}=137)$, resistant to statin treatment $(n=287)$ and healthy controls $(n=408)$ were determined by ELISA. Result is depicted as box plots; middle line indicates median; bottom of box, 25th percentile; and top of box, 75th percentile. ${ }^{*} \mathrm{P}<0.05$. (E) Percentage change of the LDL level comparing with the baseline values after $10 \mathrm{mg}$ Atorvastatin treatment between the hyperlipidemia patients sensitive $(n=137)$ and resistant to statin treatment $(\mathrm{n}=287) .{ }^{*} \mathrm{P}<0.05$. ( $\left.\mathrm{F}\right)$ Correlation between plasma IL-38 $(\mathrm{ng} / \mathrm{mL})$ and the percentage of the reduction of LDL levels. $\mathrm{P}<0.05$. Inset corresponds to Pearson's R correlation and corresponding P value.

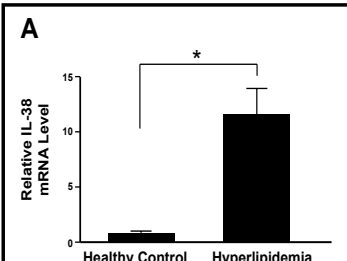

B

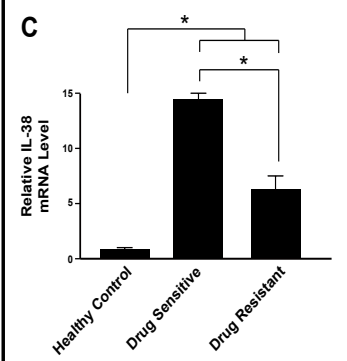

D

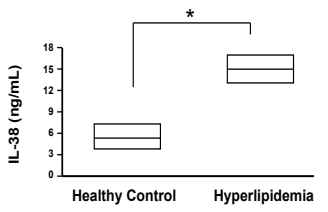

E

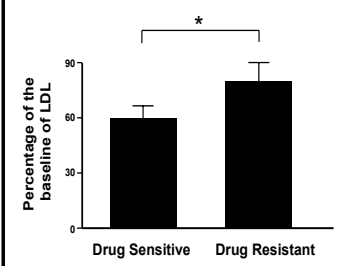

F
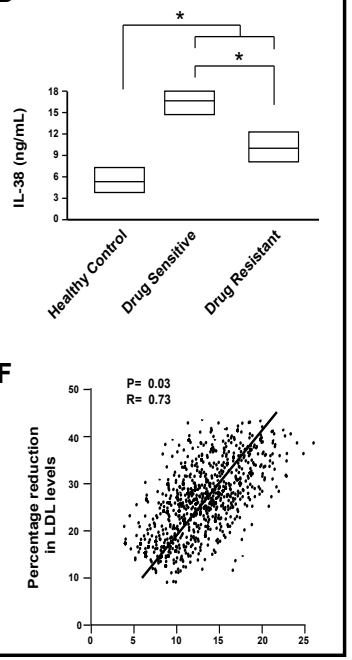
group, according to their response to Atorvastatin therapy following four weeks of treatment with $10 \mathrm{mg} /$ day Atorvastatin. The patients sensitive to the Atorvastatin (Drug Sensitive) were defined as their ideal LDL goal (LDL $<115 \mathrm{mg} / \mathrm{dl}$ ) [1]. Otherwise, they were defined as Atorvastatin resistant group (Drug Resistant). Data showed that both the mRNA and protein levels of IL-38 were significantly highly expressed in the patients sensitive to Atorvastatin therapy than the resistant group (Fig. 1C-1D). And the Atorvastatin was more effective in the Drug Sensitive group than the Drug Resistant group (Fig. 1E). Furthermore, the plasma IL-38 level was positively correlated with the percentage of the reduction of LDL levels (Fig. 1F). Thus the IL-38 level might associate with the clinical responses to the Atorvastatin therapy.

\section{IL-38 Suppress Inflammatory factors expression in} Hyperlipidemia Patients

As hyperlipidemia is tightly associated with inflammation [1619] and the IL-38 represents a new identified anti-inflammatory factor $[20,21]$, we further studied whether IL-38 could suppress the inflammatory factors expression in the cultured hyperlipidemia patients' PBMCs treated with recombinant human IL-38 protein. As expected, the pro-inflammatory factors IL-6, CRP and IL-1 $\beta$ were highly expressed in the hyperlipidemia patients` PBMCs than healthy control at both mRNA level and protein level (Fig. 2A-2B). Interestingly, administrating human recombinant IL-38 at $50 \mathrm{ng} / \mathrm{ml}$ for 24 hours could significantly suppress their expression at both mRNA level and protein level (Fig. 2A-2B).

\section{IL-38 Suppresses Hyperlipidemia} and Atherosclerosis by Limiting Inflammation

To further investigate the role of IL-38 in hyperlipidemia development and treatment, $\mathrm{ApoE}^{-/-}$mice were fed with an HCD (high-cholesterol diet) for 12 weeks. The
Table 1. Clinical features of the participants. All patients and healthy controls were male. BMI: body mass index; TC: total cholesterol; TG: Triglyceride; HDL: highdensity lipoprotein; LDL: low-density lipoprotein; IL38: Interleukin-38. FRS: Framingham risk score; ASCVD: atherosclerotic cardiovascular disease risk score. ${ }^{*} \mathrm{P}<$ 0.05 indicates a significant difference. Data were shown as mean $\pm S E$ or median (interquartile range)

\begin{tabular}{lccc}
\hline & Hyperlipidemia $(\mathrm{n}=424)$ & Control $(\mathrm{n}=408, \%)$ & P value \\
\hline Age (years) & $54.5 \pm 4.4$ & $57.01 \pm 5.7$ & 0.245 \\
FRS & $3.6 \pm 1.2$ & $3.1 \pm 1.0$ & 0.248 \\
ASCVD & $2.4 \pm 1.4$ & $1.9 \pm 1.1$ & 0.154 \\
BMI $\left(\mathrm{kg} / \mathrm{m}^{2}\right)$ & $24.05 \pm 1.45$ & $24.24 \pm 1.95$ & 0.857 \\
TC $(\mathrm{mg} / \mathrm{dl})$ & $278.6(256.8-311.5)$ & $169.5(148.6-178.3)$ & $0.005^{*}$ \\
TG $(\mathrm{mg} / \mathrm{dl})$ & $228.9(198.5-295.6)$ & $95.6(78.6-110.8)$ & $0.001^{*}$ \\
LDL $(\mathrm{mg} / \mathrm{dl})$ & $152.5(135.8-175.9)$ & $88.6(68.5-108.9)$ & $0.007^{*}$ \\
HDL $(\mathrm{mg} / \mathrm{dl})$ & $31.9(25.7-44.2)$ & $45.6(30.2-56.8)$ & $0.044^{*}$ \\
IL-38 $(\mathrm{ng} / \mathrm{mL})$ & $15.9 \pm 3.3$ & $5.1 \pm 1.2$ & $<0.001^{*}$ \\
\hline
\end{tabular}

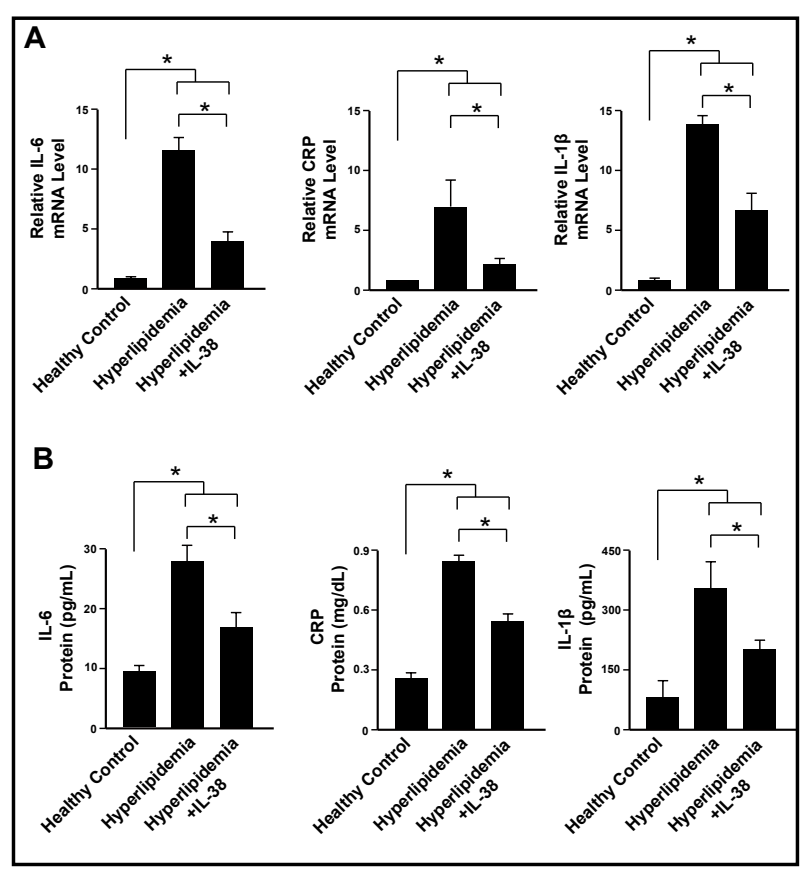

Fig. 2. Recombinant IL-38 protein suppresses the secretion of pro-inflammatory factors. PBMCs from hyperlipidemia patients $(\mathrm{n}=424)$ were stimulated with or without IL-38 $(50 \mathrm{ng} / \mathrm{ml})$ for 24 hour. PBMCs from healthy controls ( $\mathrm{n}=$ 408 ) were used as controls. The pro-inflammatory factor IL-6, CRP and IL-1 $\beta$ were analyzed. The cells were lysed for mRNA analysis via RT-PCR (A) and the supernatants were examined using ELISA (B). ${ }^{*} \mathrm{P}<0.05$. CRP: C-reactive protein; IL: interleukin. 
Fig. 3. IL-38 overexpression suppresses the hyperlipidemia and atherosclerosis in the mice model. (A) Hyperlipidemia mice model was established by feeding ApoE ${ }^{-/-}$mice with HCD (high-cholesterol diet) for 12 weeks. The TC, TG, LDL and IL-38 levels were measured $(\mathrm{n}=12)$. * $\mathrm{P}<0.05$. (B) IL-38 overexpression was performed by delivering AAV-IL-38 every 3 weeks. The mRNA of IL-38 in the thoracoabdominal aorta was determined by qPCR $(n=12) .{ }^{*} \mathrm{P}<0.05$. (C) The serum TC, TG and LDL levels were measured in the mice treated with AAV-GFP or AAV-IL-38 $(\mathrm{n}=12) .{ }^{*} \mathrm{P}<0.05$. (D) The atherosclerosis lesion areas in the thoracoabdominal aorta were measured in the mice treated with AAV-GFP or AAV-IL-38 ( $\mathrm{n}=12)$. * $\mathrm{P}<0.05$. (E) Representative figures for the atherosclerosis lesion areas in the thoracoabdominal aorta. (F) The proinflammatory factor IL-6, CRP and IL-1 $\beta$ levels in the mice treated with AAV-GFP or AAV-IL-38 were analyzed $(\mathrm{n}=12){ }^{*} \mathrm{P}<0.05$. CRP: C-reactive
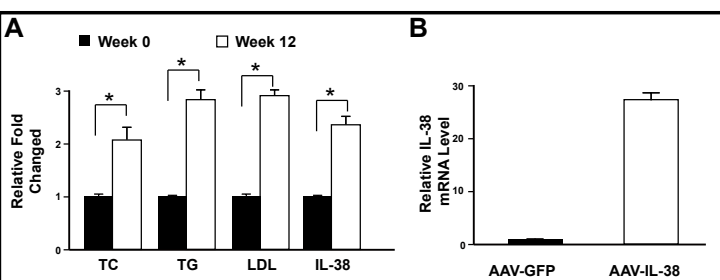

C

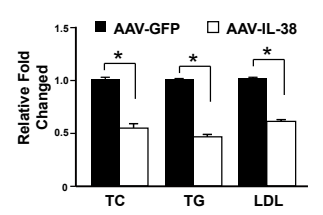

D

$E$
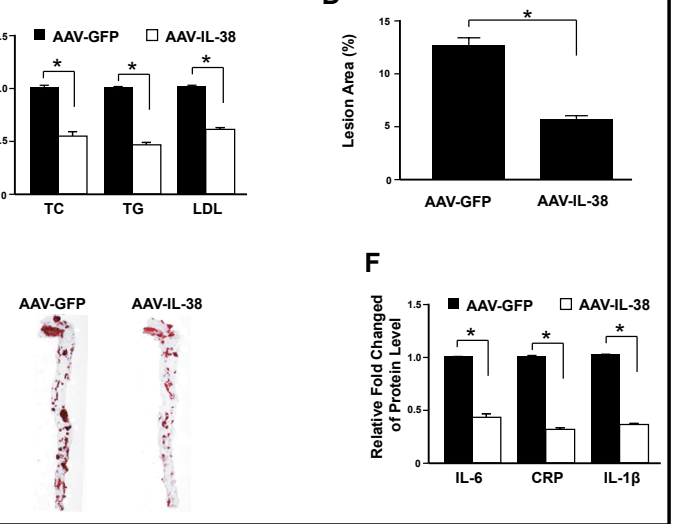

protein; IL: interleukin; TC: total cholesterol; TG:

triglyceride; LDL: low-density lipoprotein cholesterol; AAV: adeno-associated virus.

TC, TG and LDL levels were elevated at week 12 comparing with week 0 after HCD treatment (Fig. 3A). Furthermore, the IL-38 level was also increased, which is in accordance with the clinical data (Fig. 3A, Fig. 1A-1B). Overexpressing the IL-38 via AAV delivery every 3 weeks significantly decreased the TC, TG and LDL levels (Fig. 3B-3C). In addition, the size of the atherosclerotic lesions in the thoracoabdominal aorta was reduced by AAV-IL38 (Fig. 3D-3E). Inflammation is a key component during the initiation and progression of atherosclerosis [31]. Therefore, we also measured the pro-inflammatory factor IL-6, CRP and IL-1 $\beta$ expression in the hyperlipidemia mice model treated with or without AAV-IL38. Data showed that overexpressing IL-38 significantly suppressed these pro-inflammatory factors expression (Fig. 3F). These data suggest that the alleviated atherosclerotic lesion formation by IL-38 overexpression might be attributed to inflammation suppression.

\section{Discussion}

At present, hyperlipidemia is an important global health concern [5]. Hyperlipidemia is the presence of increased or abnormal levels of lipids and/or lipoproteins in the blood and a strong risk factor for atherosclerosis, stroke, CAD (coronary artery disease) and myocardial infarction (MI), such as elevated levels of total cholesterol (TC), triglyceride (TG), low-density lipoprotein cholesterol (LDL) or decreased level of high-density lipoprotein cholesterol (HDL) [1, 32]. Furthermore, hyperlipidemia also associates with obesity, insulin resistance and nonalcoholic fatty liver disease (NAFLD), which are important features of metabolic syndrome [33].

Because chronic inflammation is tightly associated with hyperlipidemia [16-19] and IL38 is a new identified anti-inflammatory factor [20,21], we studied the important role of IL-38 in hyperlipidemia development and treatment in the current study. The mRNA level of IL-38 in PBMCs and also the protein level in the serum were higher in hyperlipidemia patients compared with the healthy controls. Furthermore, the IL-38 levels were higher in patients sensitive to Atorvastatin therapy than the resistant group. In vitro, IL-38 inhibited the production of IL-6, IL-1 $\beta$ and CRP in PBMCs of patients with hyperlipidemia.

\section{KARGER}




\section{Cellular Physiology Cell Physiol Biochem 2018;49:653-661

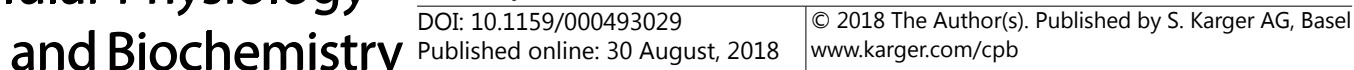 \\ Yang et al.: Elevated IL-38 Associates with Atorvastatin Response}

In order to confirm the reliability of the clinical results, a high-fat diet induced hyperlipidemia mice model was used. In the mice model of hyperlipidemia, IL-38 was also elevated during the hyperlipidemia development. And the IL-38 overexpression by AAV significantly inhibited the hyperlipidemia development, inflammatory factor expression and also the atherosclerosis process. Thus our data showed that IL-38 might present protective effects on hyperlipidemia treatment.

Atherosclerosis is a multi-factorial disorder of the heart vessels that develops over decades, coupling inflammatory mechanisms and elevated total cholesterol levels under the influence of genetic and environmental factors. Without effective intervention, atherosclerosis consequently causes coronary heart disease (CHD), which leads to increased risk of sudden death [18]. It is a chronic inflammatory disorder of the vessel wall, where both innate and adaptive immune responses influence disease progression [19]. This involves: impairment of endothelial cell (EC) function; accumulation of cholesterol in subendothelial macrophage-derived foam cells; adherence and recruitment of leukocytes into the arterial wall; proliferation and migration of smooth muscle cells into the intima; activation and aggregation of platelets; $\mathrm{T}$ cell activation; and production of inflammatory cytokines [34]. The innate signals within the lesion can arise from various sources and promote atherosclerosis through inflammatory processes. Oxidized low-density lipoprotein (LDL) accumulation, starting in the fatty streaks, promotes the inflammatory response, which most likely continues throughout lesion development. Furthermore, pathogenic infection and endogenous danger signals increase during tissue injury and have been implicated as inducers of lesion inflammation [34].

Previous studies have shown that targeting inflammation might represent an alternative approach to suppress the hyperlipidemia and also the atherosclerosis [31, 35, 36]. Our data here demonstrated that IL-38, a newly identified anti-inflammatory factor, also showed protective effect during hyperlipidemia treatment in the clinic and alleviated atherosclerosis development in the mice model. Thus, IL-38 could be a potential candidate for immunotherapy in the hyperlipidemia and atherosclerosis. However, the manner in which IL-38 sensitizes hyperlipidemia patients to statin therapy is not well known. Therefore, further studies are needed to determine the exact mechanism of action of IL-38 in the hyperlipidemia.

\section{Acknowledgements}

This work was supported by the Fund for key project of Science and Technology of Tianjin Health and Family Planning Commission (2015KR07) and key projectof Science and Technology of Tianjin Health and Family PlanningCommission(13KG131).

NY design and conduct the experiment; YS, BD, YL, LK and JY conduct the experiment and collect the data; $\mathrm{QQ}$ design the experiment, analyze the data and write the manuscript.

\section{Disclosure Statement}

The authors declare that they have no competing interests.

\section{References}

1 National Cholesterol Education Program Expert Panel on Detection E, Treatment of High Blood Cholesterol in A: Third Report of the National Cholesterol Education Program (NCEP) Expert Panel on Detection, Evaluation, and Treatment of High Blood Cholesterol in Adults (Adult Treatment Panel III) final report. Circulation 2002;106:3143-3421. 


\section{Cellular Physiology Cell Physiol Biochem 2018;49:653-661 \begin{tabular}{ll|l} 
and Biochemistry & DOI: 10.1159/000493029 & $\begin{array}{l}\text { (C) } 2018 \text { The Author(s). Published by S. Karger AG, Basel } \\
\text { www.karger.com/cpb }\end{array}$
\end{tabular}}

-2 Expert Panel on Detection E, Treatment of High Blood Cholesterol in A: Executive Summary of The Third Report of The National Cholesterol Education Program (NCEP) Expert Panel on Detection, Evaluation, And Treatment of High Blood Cholesterol In Adults (Adult Treatment Panel III). JAMA 2001;285:2486-2497. Giansanti R, Rabini RA, Romagnoli F, Fumelli D, Sorichetti P, Boemi M, Fumelli P: Coronary heart disease, type 2 diabetes mellitus and cardiovascular disease risk factors: a study on a middle-aged and elderly population. Arch Gerontol Geriatr 1999;29:175-182.

-4 Asztalos BF, Roheim PS, Milani RL, Lefevre M, McNamara JR, Horvath KV, Schaefer EJ: Distribution of ApoA-I-containing HDL subpopulations in patients with coronary heart disease. Arterioscler Thromb Vasc Biol 2000;20:2670-2676.

5 Writing Group M, Mozaffarian D, Benjamin EJ, Go AS, Arnett DK, Blaha MJ, Cushman M, Das SR, de Ferranti S, Despres JP, Fullerton HJ, Howard VJ, Huffman MD, Isasi CR, Jimenez MC, Judd SE, Kissela BM, Lichtman JH, Lisabeth LD, Liu S, et al.: Executive Summary: Heart Disease and Stroke Statistics--2016 Update: A Report From the American Heart Association. Circulation 2016;133:447-454.

6 Adams SP, Tsang M, Wright JM: Lipid-lowering efficacy of atorvastatin. Cochrane Database Syst Rev 2015; DOI:10.1002/14651858.CD008226.pub3CD008226.

7 Superko HR, Momary KM, Li Y: Statins personalized. Med Clin North Am 2012;96:123-139.

8 Tosi I, Toledo-Leiva P, Neuwirth C, Naoumova RP, Soutar AK: Genetic defects causing familial hypercholesterolaemia: identification of deletions and duplications in the LDL-receptor gene and summary of all mutations found in patients attending the Hammersmith Hospital Lipid Clinic. Atherosclerosis 2007;194:102-111.

-9 Grundy SM, Cleeman JI, Merz CN, Brewer HB Jr, Clark LT, Hunninghake DB, Pasternak RC, Smith SC, Jr., Stone NJ, National Heart L, Blood I, American College of Cardiology F, American Heart A: Implications of recent clinical trials for the National Cholesterol Education Program Adult Treatment Panel III guidelines. Circulation 2004;110:227-239.

-10 Zuo Y, Wang Y, Hu H, Cui W: Atorvastatin Protects Myocardium Against Ischemia-Reperfusion Injury Through Inhibiting miR-199a-5p. Cell Physiol Biochem 2016;39:1021-1030.

11 Yue YH, Bai XD, Zhang HJ, Li YM, Hu L, Liu LY, Mao JP, Yang XY, Dila NM: Gene Polymorphisms Affect the Effectiveness of Atorvastatin in Treating Ischemic Stroke Patients. Cell Physiol Biochem 2016;39:630-638.

-12 Wang J, Chen H, Zhou Y, Su Q Liu T, Wang XT, Li L: Atorvastatin Inhibits Myocardial Apoptosis in a Swine Model of Coronary Microembolization by Regulating PTEN/PI3K/Akt Signaling Pathway. Cell Physiol Biochem 2016;38:207-219.

13 Lu J, Hao J, Du H, Xiao B, Li Y, Yang X, Cui W: Amlodipine and Atorvastatin Improved Hypertensive Cardiac Remodeling through Regulation of MMPs/TIMPs in SHR Rats. Cell Physiol Biochem 2016;39:47-60.

14 Liang J, Yin K, Cao X, Han Z, Huang Q, Zhang L, Ma W, Ding F, Bi C, Feng D, Pan Z, Liu Y: Attenuation of Low Ambient Temperature-Induced Myocardial Hypertrophy by Atorvastatin via Promoting Bcl-2 Expression. Cell Physiol Biochem 2017;41:286-295.

15 Chen S, Dong S, Li Z, Guo X, Zhang N, Yu B, Sun Y: Atorvastatin Calcium Inhibits PDGF-betabeta-Induced Proliferation and Migration of VSMCs Through the G0/G1 Cell Cycle Arrest and Suppression of Activated PDGFRbeta-PI3K-Akt Signaling Cascade. Cell Physiol Biochem 2017;44:215-228. Falk E: Pathogenesis of atherosclerosis. J Am Coll Cardiol 2006;47:C7-12. Libby P: Inflammation in atherosclerosis. Nature 2002;420:868-874.

18 Lusis AJ: Atherosclerosis. Nature 2000;407:233-241.

19 Hansson GK: Inflammation, atherosclerosis, and coronary artery disease. N Engl J Med 2005;352:16851695.

20 Bensen JT, Dawson PA, Mychaleckyj JC, Bowden DW: Identification of a novel human cytokine gene in the interleukin gene cluster on chromosome 2q12-14. J Interferon Cytokine Res 2001;21:899-904.

21 Lin H, Ho AS, Haley-Vicente D, Zhang J, Bernal-Fussell J, Pace AM, Hansen D, Schweighofer K, Mize NK, Ford JE: Cloning and characterization of IL-1HY2, a novel interleukin-1 family member. J Biol Chem 2001;276:20597-20602.

-22 van de Veerdonk FL, Stoeckman AK, Wu G, Boeckermann AN, Azam T, Netea MG, Joosten LA, van der Meer JW, Hao R, Kalabokis V, Dinarello CA: IL-38 binds to the IL-36 receptor and has biological effects on immune cells similar to IL-36 receptor antagonist. Proc Natl Acad Sci U S A 2012;109:3001-3005. 


\section{Cellular Physiology Cell Physiol Biochem 2018;49:653-661 \begin{tabular}{ll|l} 
DOI: 10.1159/000493029 & $\begin{array}{l}\text { O 2018 The Author(s). Published by S. Karger AG, Basel } \\
\text { www.karger.com/cpb }\end{array}$
\end{tabular}}

Yang et al.: Elevated IL-38 Associates with Atorvastatin Response

23 Dehghan A, Dupuis J, Barbalic M, Bis JC, Eiriksdottir G, Lu C, Pellikka N, Wallaschofski H, Kettunen J, Henneman P, Baumert J, Strachan DP, Fuchsberger C, Vitart V, Wilson JF, Pare G, Naitza S, Rudock ME, Surakka I, de Geus EJ et al.: Meta-analysis of genome-wide association studies in $>80000$ subjects identifies multiple loci for C-reactive protein levels. Circulation 2011;123:731-738.

-24 Sabater-Lleal M, Huang J, Chasman D, Naitza S, Dehghan A, Johnson AD, Teumer A, Reiner AP, Folkersen L, Basu S, Rudnicka AR, Trompet S, Malarstig A, Baumert J, Bis JC, Guo X, Hottenga JJ, Shin SY, Lopez LM, Lahti J et al.: Multiethnic meta-analysis of genome-wide association studies in $>100000$ subjects identifies 23 fibrinogen-associated Loci but no strong evidence of a causal association between circulating fibrinogen and cardiovascular disease. Circulation 2013;128:1310-1324.

25 Jha HC, Srivastava P, Vardhan H, Singh LC, Bhengraj AR, Prasad J, Mittal A: Chlamydia pneumoniae heat shock protein 60 is associated with apoptotic signaling pathway in human atheromatous plaques of coronary artery disease patients. J Cardiol 2011;58:216-225.

-26 Catapano AL, Graham I, De Backer G, Wiklund O, Chapman MJ, Drexel H, Hoes AW, Jennings CS, Landmesser U, Pedersen TR, Reiner Z, Riccardi G, Taskinen MR, Tokgozoglu L, Verschuren WMM, Vlachopoulos C, Wood DA, Zamorano JL, Cooney MT, Group ESCSD: 2016 ESC/EAS Guidelines for the Management of Dyslipidaemias. Eur Heart J 2016;37:2999-3058.

-27 Stone NJ, Robinson JG, Lichtenstein AH, Bairey Merz CN, Blum CB, Eckel RH, Goldberg AC, Gordon D, Levy D, Lloyd-Jones DM, McBride P, Schwartz JS, Shero ST, Smith SC, Jr., Watson K, Wilson PW, Eddleman KM, Jarrett NM, LaBresh K, et al.: 2013 ACC/AHA guideline on the treatment of blood cholesterol to reduce atherosclerotic cardiovascular risk in adults: a report of the American College of Cardiology/American Heart Association Task Force on Practice Guidelines. Circulation 2014;129:S1-45.

-28 Wilson PW, D’Agostino RB, Levy D, Belanger AM, Silbershatz H, Kannel WB: Prediction of coronary heart disease using risk factor categories. Circulation 1998;97:1837-1847.

29 D’Agostino RB, Sr., Vasan RS, Pencina MJ, Wolf PA, Cobain M, Massaro JM, Kannel WB: General cardiovascular risk profile for use in primary care: the Framingham Heart Study. Circulation 2008;117:743-753.

30 Goff DC, Jr., Lloyd-Jones DM, Bennett G, Coady S, D’Agostino RB, Gibbons R, Greenland P, Lackland DT, Levy D, O’Donnell CJ, Robinson JG, Schwartz JS, Shero ST, Smith SC, Jr., Sorlie P, Stone NJ, Wilson PW, Jordan HS, et al.: 2013 ACC/AHA guideline on the assessment of cardiovascular risk: a report of the American College of Cardiology/American Heart Association Task Force on Practice Guidelines. Circulation 2014;129:S4973.

-31 Tietge UJ: Hyperlipidemia and cardiovascular disease: inflammation, dyslipidemia, and atherosclerosis. Curr Opin Lipidol 2014;25:94-95.

-32 Do R, Willer CJ, Schmidt EM, Sengupta S, Gao C, Peloso GM, Gustafsson S, Kanoni S, Ganna A, Chen J, Buchkovich ML, Mora S, Beckmann JS, Bragg-Gresham JL, Chang HY, Demirkan A, Den Hertog HM, Donnelly LA, Ehret GB, Esko T et al.: Common variants associated with plasma triglycerides and risk for coronary artery disease. Nat Genet 2013;45:1345-1352.

-33 Morrish NJ, Wang SL, Stevens LK, Fuller JH, Keen H: Mortality and causes of death in the WHO Multinational Study of Vascular Disease in Diabetes. Diabetologia 2001;44:S14-21.

34 Xu JY, Lee YK, Wang Y, Tse HF: Therapeutic application of endothelial progenitor cells for treatment of cardiovascular diseases. Curr Stem Cell Res Ther 2014;9:401-414.

-35 Tous M, Ribas V, Escola-Gil JC, Blanco-Vaca F, Calpe-Berdiel L, Coll B, Ferre N, Alonso-Villaverde C, Rull A, Camps J, Joven J: Manipulation of inflammation modulates hyperlipidemia in apolipoprotein E-deficient mice: a possible role for interleukin-6. Cytokine 2006;34:224-232.

-36 Bagchi S, He Y, Zhang H, Cao L, Van Rhijn I, Moody DB, Gudjonsson JE, Wang CR: CD1b-autoreactive T cells contribute to hyperlipidemia-induced skin inflammation in mice. J Clin Invest 2017;127:2339-2352. 